\title{
Relationship Between Capital Structure and Stock Returns of Jordanian Commercial Banks
}

\author{
Sufian Radwan Al-Manaseer ${ }^{1}$ \\ ${ }^{1}$ Business Economic Department, Business Faculty, Tafila Technical University, Jordan \\ Correspondence: Dr. Sufian Radwan Al-Manaseer, P. O. Box 179, Tafila 66110, Jordan.
}

Received: December 20, 2019

Accepted: January 20, 2020

Online Published: January 21, 2020

doi:10.5539/ibr.v13n2p100

URL: https://doi.org/10.5539/ibr.v13n2p100

\begin{abstract}
This study aims to analyze the relationship between capital structure and stock returns of Jordanian banks listed on the Amman Stock Exchange from 2009 to 2018. The study sample is composed of 13 commercial banks in Jordan. The e-views program is used to conduct the statistical analysis of study variables. Initially, a simple linear regression analysis is conducted to determine the impact of capital structure as measured by financial leverage on stock returns and vice versa. Then, several control variables are added: growth in assets, liquidity, firm size, and profitability. This study has found that growth, capital structure, and profitability have a positive impact on stock returns. By contrast, liquidity and firm size have a negative impact on stock returns. Stock returns and firm size have a positive impact on capital structure, whereas liquidity, growth, and profitability have a negative impact on capital structure.
\end{abstract}

Keywords: capital structure, stock returns, growth in assets, liquidity, firm size, profitability, banks

\section{Introduction}

Although the decisions involve in capital structure remain unclear, capital structure has an important role in firms' sustainability (Ahmad et al., 2013). Therefore, knowing the changes in capital structure is important, given that these changes affect firms' performances; the higher the financial leverage, the higher of bankruptcy risk and required rate of return by shareholders (Khan et al., 2013).

Hass (2002) has indicated that firms attempt to manage their financial statements efficiently to declare a fixed return per share. Firms also attempt to control capital structure and return appropriately. In case debt ratio rises, a similar increase will also occur in stock returns. Stock returns will lead to an increase in the cost of capital and a decrease in the ability to pay obligations, which may lead to a financial crisis; thus, firms prefer to decrease debt financing to avoid the potential effects of defaulting on their liabilities (Dudley \& James, 2015).

Given that actual returns differ from expected returns, investors prefer high-yield investments commensurate with their high risk (Bodie et al., 2008). Modigliani and Miller (1958) have noted that the expected return on equity should increase with the increase in debt in capital structure of a company in the friction market. The higher the debt ratio, the higher the return investors will demand due to the higher risk of company's inability to meet obligations. This risk is reflected by the decline in stock prices.

Bhandari (1988) has suggested that capital structure has a direct impact on stock returns, thereby affecting firms' performances. Therefore, stock market returns are important for investors, given that returns directly affect their wealth (Onaolapo \& Kajola, 2010). Chowdhury and Chowdhury (2010) have pointed out that firms' market values are linked to share values, affecting firm owners' wealth.

However, regulations vary from country to country; thus, capital structure is expected to vary among different countries, industries, and firms (Muzir, 2011). Private firms rely more on debt financing than government firms (Brav, 2009).

Considerable research has explored the determinants of capital structure or stock returns, but only few studies have examined the relationship between capital structure and stock returns. Baker and Wurgler (2002) and Welch (2004) have argued that stock returns are determinant of capital structure, which is contradicting with Bhandari (1988) who noted that capital structure is determinant of stock returns. Other studies (Yang et al., 2010) have provided evidence that capital structure and stock returns affect each other simultaneously. 
Ideal capital structure remains one of the most controversial topics among researchers. No general agreement has been made on the relationship between capital structure and stock returns (Onaolapo \& Kajola, 2010). Moreover, due to the lack of sufficient studies on the Jordanian companies listed on the Amman Stock Exchange (AME). Thus, this study aims to fill the research gap by examining the relationship between capital structure and stock returns in Jordanian commercial banks listed on the AME from 2009 to 2018. A set of control variables, including growth in assets, liquidity, firm size, and profitability, is also explored inspired by previous research (Yang et al., 2010; Ahmad et al., 2013). The study problem could be clarified by answering the following questions:

\section{What is the impact of capital structure on stock returns of Jordanian commercial banks?}

2. What is the impact of stock returns on capital structure of Jordanian commercial banks?

This study will help to increase the knowledge on the relationship between capital structure and stock returns, which can assist investors in choosing their investments and future researchers in covering the deficiencies in clarifying the relationship between capital structure and stock returns.

This study is organized as follows. The first part introduces studies on capital structure and stock returns. The second part reviews related literature and theoretical frameworks. The third part discusses the methodology, hypotheses, population and sample, data collection methods, mathematical model, and variable measurement methods in this study. The fourth part conducts the statistical analysis and hypotheses test and discusses the results. The fifth part provides the conclusion, recommendations, and limitations of this study.

\section{Theoretical Framework and Literature Review}

Capital structure represents a mixture of equity and debt (Ilyas, 2008). Umar et al. (2012) have noted that equity and debt are the main options for companies to fund their operations. According to Örtqvist et al. (2006), the capital structure is measured by financial leverage ratios, such as the debt ratio, which is the total liabilities to total assets, or the debt to equity ratio, which is the total debt to total equity. However, these ratios are subject to change, either due to increased borrowing or as a result of changes in the market valuation of equity.

Numerous theories have discussed capital structure in an attempt to reach an optimal capital structure by balancing debt and equity. Modigliani and Miller (1958) have pointed out that no mix of capital structure is optimal and that the cost of capital is not related to the manner and type of financing used by firm. Therefore, capital structure has no impact on firms' values. Jahanzeb (2013) has argued that capital structure decision remains affected by trade-off, pecking order, and market timing theories.

In trade-off theory, Myers (1984) has pointed out that capital structure options are a trade-off between benefits and borrowing costs. In pecking order theory, Myers and Majluf (1984) have pointed out that firms have a particular preference for capital financing options due to the varying costs of these sources. Accordingly, firms prefer internal financing to external financing. Antoniou, Guney, and Paudyal (2008) have discussed that under trade-off and pecking order theories, firms with volatile returns would have difficulty borrowing due to low yields, which is insufficient and will not able to meet their obligations.

Stock returns represent the gain or loss in stock value over a specific period (Mugambi \& Okech, 2016). Frimpong (2010) has defined stock returns as the amount received from investments. Thus, investors will invest if the return is higher than the cost. Investors who buy stocks expect returns as cash dividends or capital gains, which are represented in a rise in stock prices. The increase in stock returns indicates a rise in firm profits, which contributes to economic growth (Aliyu, 2011).

High stock returns will lead to an increase in the assets market value and a decrease in debt ratio, indicating the negative impact of stock returns on financial leverage (Yang et al., 2010). By contrast, if the debt ratio rises, investors will demand a high return due to the high risk of bankruptcy, indicating the positive impact of financial leverage on stock returns (Bhandari, 1988; Yang et al., 2010). However, the fluctuation in stock price creates uncertainty for investors, which is reflected in stock demand and supply (Taofik \& Omosola, 2013).

\subsection{Literature Review}

Studies have investigated the determinants of capital structure and stock returns and the impact of capital structure on firms' performances. However, only few of these studies have examined the relationship between capital structure and stock returns and their impact on each other.

Yang et al. (2010) have conducted a study (Co-determination of capital structure and stock returns - A LISREL approach: An empirical test of Taiwan stock markets) on 662 non-financial Taiwanese companies from 2003 to 2005. They have found that capital structure and stock returns affect each other simultaneously. Moreover, debt 
ratio, profitability, and growth have a positive impact on stock returns; whereas, stock returns, profitability, and growth have negative impact on financial leverage.

Khan et al. (2013) have conducted a study (Impact of Capital Structure and Financial Performance on Stock Returns) on 69 Pakistani textile companies from 2003 to 2009 and concluded that the financial leverage positively affects stock returns.

Ahmad et al. (2013) have conducted a study (The Co-determinants of Capital Structure and Stock Returns: Evidence from the Karachi Stock Exchange) on 100 non-financial firms listed on the Karachi Stock Exchange from 2006 to 2010. They have found that financial leverage and stock returns affect each other negatively. Although profitability and growth have a positive effect and liquidity has a negative effect on stock returns, firm size does not affect stock returns. Firm size, profitability, and liquidity have a negative effect on financial leverage, whereas growth has a positive effect on financial leverage.

Al-Yahyaee et al. (2013) have conducted a study (Capital structure and stock returns: Evidence from an emerging market with unique financing arrangements) on listed firms on the Muscat Securities Market from 1989 to 2003. They have found that stock returns determine capital structure. Stock returns stimulate some of the issuance activities in firms in which managers use the issuance process to counter some of the mechanical impacts of stock returns.

Bergrren and Bergqvist (2014) have conducted a study (Capital Structure and Stock Returns-A study of the Swedish large-cap companies) on 50 Swedish firms from 2009 to 2013. They have found that growth, financial leverage, and liquidity have a positive impact on stock returns, whereas profitability has a negative impact on stock returns. Firm size has a significant impact on stock returns and financial leverage.

Gharaibeh (2014) have conducted a study (Capital structure, Liquidity, and Stock returns) on 15 industrial firms listed on the Amman Stock Exchange from 2009 to 2012. They have found that liquidity and capital structure have a weak negative effect on stock returns. Likewise, stock returns and liquidity have a weak negative effect on capital structure.

Acheampong et al. (2014) have conducted a study (The Effect of Financial Leverage and Market Size on Stock Returns on the Ghana Stock Exchange: Evidence from Selected Stocks in the Manufacturing Sector) on five industrial firms from 2006 to 2010. They have found that a statistically negative relationship exists between financial leverage and stock returns, whereas a statistically positive relationship exists between firm size and stock returns.

Al-Salamat and Mustafa (2016) have conducted a study (The Impact of Capital Structure on Stock Return: Empirical Evidence from Amman Stock Exchange) on all industrial firms listed on the Amman Stock Exchange from 2007 to 2014. They have found capital structure has a negative impact on stock returns, whereas stock liquidity and return on assets have a positive impact on stock returns.

Ali (2017) has conducted a study (Impact of Capital Structure on Stock Return in Oil \& Gas Sector of Pakistan) on 10 oil and gas firms operating in Pakistan from 2005 to 2014. He has found that financial leverage has a positive impact on stock returns.

Aharon and Yagil (2019) have conducted a study (The Impact of Financial Leverage on the Variance of Stock Returns) on 182 American industrial firms from 2003 to 2007. They have found that stock returns are positively correlated with financial leverage.

To the best of our knowledge, only two existing studies have investigated Jordanian firms listed in the Amman Stock Exchange: Gharaibeh (2014) and Al-Salamat and Mustafa (2016).

This study differs from other studies as follows:

1. The period of the study was 2009-2018. Gharaibeh's (2014) study was from 2009 to 2012, whereas Al-Salamat and Mustafa's (2016) study was from 2007 to 2014.

2. With regard to study samples, all Jordanian commercial banks listed on the Amman Stock Exchange were covered in this study. Gharaibeh (2014) used a sample of 15 Jordanian industrial firms from different industrial sectors. Al-Salamat and Mustafa (2016) conducted their study on all Jordanian industrial firms listed on the Amman Stock Exchange.

3. With regard to study variables, capital structure and stock returns in this study are considered the dependent and independent variables, respectively, to determine their effects on each other. Moreover, some control variables are added in this study: profitability, firm size, asset growth, and liquidity for each model. Gharaibeh (2014) has used two independent variables, capital structure and liquidity, and 
one dependent variable, stock returns. Al-Salamat and Mustafa (2016) have used four independent variables, earnings per share, financial leverage, firm size, and stock liquidity, and one dependent variable, stock returns.

\subsection{Study Variables}

Stock returns: Daferighe and Sunday (2012) have indicated that stock returns are usually measured by stock market indices, given that stocks performances are reflected by stock price volatility. High stock prices indicate a positive performance, whereas low stock prices indicate a negative performance. Yang et al. (2010) have indicated that the increase in stock returns leads to a higher market value of assets and a lower debt ratio. This result indicates the negative impact of stock returns on financial leverage.

Financial leverage: Several measures of financial leverage are used, including debt ratio, debt-to-equity ratio, and equity multiplier (Abor, 2005). The increase in financial leverage leads to a higher bankruptcy risk, and consequently, to higher required returns by investors on their stocks, indicating the positive impact of financial leverage on stock returns (Bhandari, 1988; Yang et al., 2010).

Firm size: Firm size is expressed by market value or total assets (Pervan \& Visic, 2012). Trade-off theory has suggested that large firms will need more debt to fund their operations. Pecking order theory has indicated that large firms are turning to internal financing rather than external financing, resulting in a higher rate of return required by investors in small firms (Gallizo \& Salvador, 2006).

Profitability: Pecking order theory has indicated that firms with high profits lead to a high rate of return on stocks, indicating the positive impact of profitability on stock returns. Trade-off theory has indicated a positive relationship between profitability and financial leverage. Previous studies (Yang et al., 2010; Chen \& Chen, 2011) have pointed out the negative impact of profitability on financial leverage.

Growth: Chen and Chen (2011) have suggested that firms' growth leads to volatility in its value, leading to high risks and high rate of return required on stocks. This situation indicates a positive relationship between growth and stock returns.

Liquidity: Liquidity reflects firm's ability to meet its obligations on time. Brealey et al. (2011) have indicated that liquidity can be measured by several ratios such as current ratio, quick-acid ratio, and change in working capital. The firms must manage liquidity well to avoid any financial crisis and maximize their profits. Pecking order theory indicates a negative relationship between liquid assets and financial leverage. Trade-off theory suggests that firms with a high rate of liquid assets have higher borrowing capacity, given their ability to repay their liabilities. Thus, a positive relationship exists between liquidity and financial leverage. Previous studies (Yang et al., 2010; Chen \& Chen, 2011) have also indicated a negative relationship between stock returns and liquidity.

\section{Methodology}

\subsection{Study Hypotheses}

$\mathrm{H}_{01}$ : Capital structure has no statistically significant impact on stock returns of Jordanian commercial banks.

$\mathrm{H}_{02}$ : Stock returns has no statistically significant impact on capital structure of Jordanian commercial banks.

$\mathrm{H}_{03}$ : Capital structure has no statistically significant impact on stock returns of Jordanian commercial banks in the presence of the controlled variables.

$\mathrm{H}_{04}$ : Stock returns has no statistically significant impact on capital structure of Jordanian commercial banks in the presence of the controlled variables.

\subsection{Population and Sample}

The population used in this study includes all Jordanian banks listed on the Amman Stock Exchange. The study sample is composed of all 13 commercial banks listed in the Amman Stock Exchange from 2009 to 2018. Moreover, the following conditions must be observed in the study sample:

1. All necessary data are available to test the variables.

2. Banks that are not merged with other banks.

3. The end of the fiscal year on $31 / 12$ of each year.

4. Financial reports of all banks are available.

5. Banks that have continued their listing in the Amman Stock Exchange. 
All data are obtained from the Securities Depository Center and the banks' annual reports.

\subsection{Mathematical Model}

In line with previous studies (Yang et al., 2010; Chen \& Chen, 2011; Ahmad et al., 2013) and the study hypotheses, the mathematical model is formulated as follows:

$$
\begin{aligned}
& \mathrm{SR}_{\mathrm{it}}=\mathrm{a}_{0}+\mathrm{a}_{1} \mathrm{LEV}_{\mathrm{it}}+\mathrm{e}_{\mathrm{it}} \\
& \mathrm{LEV}_{\mathrm{it}}=\mathrm{b}_{0}+\mathrm{b}_{1} \mathrm{SR}_{\mathrm{it}}+\mathrm{e}_{\mathrm{it}} \\
& \mathrm{SR}_{\mathrm{it}}=\mathrm{a}_{0}+\mathrm{a}_{1} \mathrm{GRTH}_{\mathrm{it}}+\mathrm{a}_{2} \mathrm{LEV}_{\mathrm{it}}+\mathrm{a}_{3} \mathrm{LIQ}_{\mathrm{it}}+\mathrm{a}_{4} \mathrm{PROF}_{\mathrm{it}}+{ }_{\mathrm{a}} \mathrm{SZE}_{\mathrm{it}}+\mathrm{e}_{\mathrm{it}} \\
& \mathrm{LEV}_{\mathrm{it}}=\mathrm{b}_{0}+\mathrm{b}_{1} \mathrm{GRTH}_{\mathrm{it}}+\mathrm{b}_{2} \mathrm{LIQ}_{\mathrm{it}}+\mathrm{b}_{3} \mathrm{PROF}_{\mathrm{it}}+\mathrm{b}_{4} \mathrm{SR}_{\mathrm{it}}+\mathrm{b}_{5} \mathrm{SZE}_{\mathrm{it}}+\mathrm{e}_{\mathrm{it}}
\end{aligned}
$$

where

$\mathrm{SR}_{\square \square}=$ stock returns ratio for the fiscal year $i$ for firm $t$;

$\mathrm{LEV}_{\text {it }}=$ financial leverage ratio for the fiscal year $i$ for firm $t$;

$\mathrm{GRTH}_{\mathrm{it}}=$ growth in assets for the fiscal year $i$ for firm $t$;

$\mathrm{LIQ}_{\mathrm{it}}=$ liquidity ratio for the fiscal year $i$ for firm $t$;

$\mathrm{PROF}_{\text {it }}=$ profitability ratio for the fiscal year $i$ for firm $t$;

$\mathrm{SZE}_{\mathrm{it}}=$ firm size for the fiscal year $i$ for firm $t$;

$\mathrm{e}_{\mathrm{it}}=$ error terms.

\subsubsection{Measurement of Mathematical Model Variables}

Stock returns: Based on previous studies (Ahmad et al., 2013; Acheampong, 2014), stock returns are measured according to the following formula:

$$
\mathrm{SR}_{i t}=\left(\mathrm{SP}_{\mathrm{it}}-\mathrm{SP}_{\mathrm{it}-1}\right) / \mathrm{SP}_{\mathrm{it}-1}
$$

where

$\mathrm{SP}_{\mathrm{it}}=$ closed stock price for the fiscal year $i$ for firm $t$;

$\mathrm{SP}_{\mathrm{it}-1}=$ closed stock price for the previous fiscal year $i$ for firm $t$.

Financial leverage: Based on previous studies (Ahmad et al., 2013; Al-Salamat \& Mustafa, 2016), financial leverage ratio is measured according to the following formula:

$$
\mathrm{LEV}_{\mathrm{it}}=\mathrm{TL}_{\mathrm{it}} / \mathrm{TA}_{\mathrm{it}}
$$

where

$\mathrm{TL}_{\mathrm{it}}=$ total liabilities for the fiscal year $i$ for firm $t$;

$\mathrm{TA}_{\mathrm{it}}=$ total assets for the fiscal year $i$ for firm $t$.

Growth: According to Ahmad et al. (2013), growth rate is measured by the growth rate of assets according to the following formula:

$$
\mathrm{GRTH}=\left(\mathrm{TA}_{\mathrm{it}}-\mathrm{TA}_{\mathrm{it}-1}\right) / \mathrm{TA}_{\mathrm{it}-1}
$$

where

$\mathrm{TA}_{\mathrm{it}}=$ total assets for the fiscal year $i$ for firm $t$;

$\mathrm{TA}_{\mathrm{it}-1}=$ total assets for the previous fiscal year $i$ for firm $t$.

Liquidity: According to Ahmad et al. (2013), liquidity ratio is measured according to the following formula: 
where

$\mathrm{CA}_{\mathrm{it}}=$ current assets for the fiscal year $i$ for firm $t$;

$\mathrm{CL}_{\mathrm{it}}=$ current liabilities for the fiscal year $i$ for firm $t$.

Profitability: Based on previous studies (Ahmad et al., 2013; Al-Salamat \& Mustafa, 2016), profitability ratio is measured according to the following formula:

$$
\mathrm{PROF}=\mathrm{NI}_{\mathrm{it}} / \mathrm{TA}_{\mathrm{it}}
$$

where

$\mathrm{NI}_{\mathrm{it}}=$ net income for the fiscal year $i$ for firm $t$;

$\mathrm{TA}_{\mathrm{it}}=$ total assets for the fiscal year $i$ for firm $t$.

Size: According to Ahmad et al. (2013), firm size is measured according to the following formula:

$$
\mathrm{SZE}=\operatorname{In}\left(\mathrm{TA}_{\mathrm{it}}\right) \ldots
$$

where

In = natural logarithm;

$\mathrm{TA}_{\mathrm{it}}=$ total assets for the fiscal year $i$ for firm $t$.

\section{Statistical Analysis}

Data variables are prepared for analysis by using Excel. Then, the e-views program is used to analyze the study data through several tests, wherein each test is suitable for its purpose. These tests are as follows:

- descriptive statistics, given the Mean and the Standard Deviation;

- multicollinearity test expressed as Durbin-Watson, in which multicollinearity problems exist if the correlation coefficient value is more than $70 \%$ (Drury, 2008);

- correlation tests that measure the strength and direction of the relationship among variables using the Pearson Correlation Matrix; and

- simple and multiple linear regression analysis tests to study the effect of independent variables on the dependent variables.

\subsection{Descriptive Statistical Analysis}

Table 1 shows the Mean and the Standard Deviation for all study variables included in the regression model for the entire sample.

Table 1. Descriptive statistics of the study variables

\begin{tabular}{|l|l|l|l|l|l|l|}
\hline & SZE & SR & PROF & LIQ & LEV & GRTH \\
\hline Mean & 9.321676 & -0.036493 & 0.012175 & 0.309854 & 66.15577 & 0.0754 \\
\hline Std. Dev. & 0.419793 & 0.160729 & 0.004834 & 0.080964 & 35.97897 & 0.09866 \\
\hline
\end{tabular}

Table 1 shows that financial leverage has the highest Mean and Standard Deviation. The Mean of financial leverage is 66.15577, indicating a high percentage of financial leverage in Jordanian commercial banks. The Standard Deviation of financial leverage is 35.97897 , indicating a high rate of variance in the financial leverage of Jordanian commercial banks.

Stock returns have the lowest Mean (0.036493), indicating a decrease in the stock returns of Jordanian commercial banks. The Standard Deviation of stock returns is 0.160729 , indicating a low variation in the rates of return for stocks in Jordanian commercial banks.

Profitability has the lowest Standard Deviation of 0.004834 , indicating a low variation in the profitability of Jordanian commercial banks. The Mean of profitability is 0.012175 , indicating a decrease in the profitability in Jordanian commercial banks. 
With regard to firm size, the Mean is 9.32 and the Standard Deviation is 0.419 , indicating a variation in the sizes of the assets of Jordanian commercial banks. This finding suggests that small and large banks are present in the study sample.

\subsection{Correlation Analysis}

To verify that multicollinearity is not a problem among the study variables, the Pearson correlation matrix is used. The results of the correlation analysis process for the study variables during the study period (2009-2018) are shown in Table 2.

Table 2. Pearson correlation among variables

\begin{tabular}{|l|l|l|l|l|l|l|}
\hline & SZE & SR & PROF & LIQ & LEV & GRTH \\
\hline SZE & 1 & & & & & \\
\hline SR & 0.0411 & 1 & & & & \\
\hline PROF & 0.0432 & 0.3074 & 1 & & & \\
\hline LIQ & 0.3720 & -0.0694 & 0.1580 & 1 & & \\
\hline LEV & -0.1247 & 0.0029 & -0.0136 & 0.1031 & 1 & \\
\hline GRTH & -0.2693 & 0.0762 & -0.0996 & 0.0892 & 0.1358 & 1 \\
\hline
\end{tabular}

As shown in Table 2, the highest correlation is $37.2 \%$ between liquidity and firm size. According to Drury (2008), if the correlation coefficient value is less than $70 \%$, multicollinearity is not a problem among the study variables.

Stock returns have a weak positive relationship with financial leverage, size, profitability, and growth, whereas a weak negative correlation with liquidity.

Leverage has a weak positive relationship with stock returns, liquidity, and growth, whereas a weak negative correlation with size and profitability.

As shown in Table 2, firm size has a weak positive relationship with stock returns, profitability, and liquidity, whereas a weak negative correlation with financial leverage and growth.

The results also show that profitability has a weak positive relationship with stock returns, liquidity, and size, whereas a weak negative correlation with financial leverage and growth.

Liquidity has a weak positive relationship with financial leverage, growth, size, and profitability, whereas a weak negative correlation with stock returns.

Growth has a weak positive relationship with stock returns, liquidity, and leverage, whereas a weak negative correlation with size and profitability.

\subsection{Hypotheses test}

Simple and multiple linear regressions are applied to test the study hypotheses, given that this study has relied on the value of the prob. to accept or reject the hypothesis. Thus, if the value of prob. is less than 0.05 , then the alternative hypothesis is accepted and the null hypothesis is rejected. The $R$-square value is also used to show the powers of the independent variables to explain the change in the dependent variables.

$\mathrm{H}_{01}$ : Capital structure has no statistically significant impact on stock returns of Jordanian commercial banks listed on the Amman Stock Exchange.

Table 3 shows the results of the simple linear regression of equation (1), which represents the first null hypothesis as follows:

$$
\mathrm{SR}_{\mathrm{it}}=\mathrm{a}_{0}+\mathrm{a}_{1} \mathrm{LEV}_{\mathrm{it}}+\mathrm{e}_{\mathrm{it}}
$$

Table 3. Result of the simple linear regression based on equation (1)

\begin{tabular}{|l|l|l|}
\hline Model & (Constant) & LEV \\
\hline Coefficients & -1.037 & 0.0151 \\
\hline t-stat. & -2.213 & 2.1365 \\
\hline Prob. & 0.0290 & 0.0349 \\
\hline Notes: implies Significance at level of 5\%; $\mathbf{R}^{2}=0.483 ;$ Adj. $\mathbf{R}^{2}=0.376 ;$ F-stat. $=4.547 ;$ D.W. $=2.01 ;$ F-prob. $=0.000$ \\
\hline
\end{tabular}


The results in Table 3 show that the correlation coefficient between the independent variable represented by financial leverage and the dependent variable represented by stock returns is 0.0151 and the prob. is 0.0349 . These findings suggest the positive impact of financial leverage on stock returns. In other words, every increase in financial leverage by $1 \%$ will lead to a rise in stock returns by $0.0151 \%$. Firms with high financial leverage will face the risk of bankruptcy, encouraging investors to demand a high return on stocks. This result is consistent with previous studies (Khan et al., 2013; Bergrren \& Bergqvist, 2014; Ali, 2017). However, this result is also inconsistent with other studies (Ahmad et al., 2013; Acheampong, 2014; Gharaibeh, 2014; Al-Salamat \& Mustafa, 2016).

The value of $t$-stat is 2.1365 , which is greater than 2. This finding indicates that Jordanian commercial banks are trying to maintain low levels of financial leverage to avoid the increase in risks (Acheampong, 2014).

The results also show that the value of R2 is 0.483 , indicating the ability of the independent variable represented by financial leverage to explain the changes in the dependent variable represented by stock returns by $48.3 \%$.

The value of the Durbin-Watson coefficient is 2.01 , confirming that no multicollinearity problem exists among the study variables (Drury, 2008).

Given that the value of prob. is less than 0.05 , we have rejected the first null hypothesis and accepted the alternative one, indicating the statistically significant impact of capital structure on stock returns for Jordanian commercial banks.

$\mathrm{H}_{02}$ : Stock returns has no statistically significant impact on capital structure of Jordanian commercial banks listed on the Amman Stock Exchange.

Table 4 represents the results of the simple linear regression of equation (2), which represents the second null hypothesis as follows:

$$
\mathrm{LEV}_{\mathrm{it}}=\mathrm{b}_{0}+\mathrm{b}_{1} \mathrm{SR}_{\mathrm{it}}+\mathrm{e}_{\mathrm{it}} \ldots
$$

Table 4. Result of the simple linear regression based on equation (2)

\begin{tabular}{|l|l|l|}
\hline Model & (Constant) & SR \\
\hline Coefficients & 66.254 & 2.7039 \\
\hline t-stat. & 425.398 & 2.1365 \\
\hline Prob. & 0.000 & 0.0349 \\
\hline Notes: implies Significance at level of $5 \% ; \mathrm{R}^{2}=0.998 ;$ Adj. $\mathrm{R}^{2}=0.997 ;$ F-stat. $=2634.24 ;$ D.W. $=0.633 ;$ F-prob. $=0.000$ \\
\hline
\end{tabular}

The results presented in Table 4 show that the correlation coefficient between the independent variable represented by stock returns and the dependent variable represented by financial leverage is 2.7039 and the prob. is 0.0349 . These results indicate the positive impact of stock returns on financial leverage. The high stock returns encourage investors to invest in the stocks of firms. Therefore, firms will resort to debt to fund their operations to achieve more stock returns. This result is contradicting with the results of previous studies (Yang et al., 2010; Ahmad et al., 2013; Acheampong, 2014; Gharaibeh, 2014).

The $t$-stat is greater than 2, given that its value has reached 2.1365. This finding indicates a decrease in stock returns of Jordanian commercial banks (Acheampong, 2014).

$\mathrm{R}^{2}=0.998$, indicating the powers of the independent variable represented by stock returns to explain the changes in the dependent variable represented by financial leverage by $99.8 \%$.

The value of the Durbin-Watson coefficient is 0.633 , confirming that no multicollinearity problem exists among the study variables (Drury, 2008).

Given that the value of prob. is less than 0.05 , we have rejected the second null hypothesis and accepted the alternative one, indicating a statistically significant impact of stock returns on capital structure of Jordanian commercial banks.

$\mathrm{H}_{03}$ : Capital structure has no statistically significant impact on stock returns of Jordanian commercial banks listed on the Amman Stock Exchange in the presence of the controlled variables.

Table 5 shows the results of the multiple linear regression of equation (3), which represents the third null hypothesis as follows:

$$
\mathrm{SR}_{\mathrm{it}}=\mathrm{a}_{0}+\mathrm{a}_{1} \mathrm{GRTH}_{\mathrm{it}}+\mathrm{a}_{2} \mathrm{LEV}_{\mathrm{it}}+\mathrm{a}_{3} \mathrm{LIQ}_{\mathrm{it}}+\mathrm{a}_{4} \mathrm{PROF}_{\mathrm{it}}+{ }_{\mathrm{a}} \mathrm{SZE}_{\mathrm{it}}+\mathrm{e}_{\mathrm{it}}
$$


Table 5. Result of the multiple linear regression based on equation (3)

\begin{tabular}{|l|l|l|l|l|l|l|}
\hline Model & (Constant) & GRTH & LEV & LIQ & PROF & SZE \\
\hline Coefficients & -1.4129 & 0.0834 & 0.0194 & -0.0361 & 12.2479 & -0.0058 \\
\hline t-stat. & -0.8275 & 0.5685 & 1.9240 & -0.1722 & 3.3691 & -0.0259 \\
\hline Prob. & 0.4098 & 0.5709 & 0.0571 & 0.8636 & 0.0011 & 0.9794 \\
\hline Notes: implies Significance at level of $5 \% ; \mathrm{R}^{2}=0.535 ;$ Adj. $\mathrm{R}^{2}=0.417 ;$ F-stat. $=4.560 ;$ D.W. $=2.17 ;$ F-prob. $=0.000$ \\
\hline
\end{tabular}

Table 5 shows that the correlation coefficient value between growth and stock returns is 0.0834 and prob. is 0.5709 , indicating the positive impact of growth on stock returns. This result may also indicate that growing firms' stocks are more valuable to investors, given that they expect to obtain a high future return from these stocks. Investors' expectations will lead to higher demand and increase in firms' market value compared with their book value. These findings are consistent with previous studies (Yang et al., 2010; Ahmad et al., 2013; Bergrren \& Bergqvist, 2014).

The correlation coefficient value between financial leverage and stock returns is 0.0194 and the prob is 0.0571 , confirming the positive impact of financial leverage on stock returns, despite the presence of controlled variables. These findings are consistent with previous studies (Khan et al., 2013; Bergrren \& Bergqvist, 2014; Ali, 2017). However, these finding are also contradicting with other studies (Ahmad et al., 2013; Acheampong, 2014; Gharaibeh, 2014; Al-Salamat \& Mustafa, 2016).

The correlation coefficient value between liquidity and stock returns is 0.0361 and the prob. is 0.8636 , indicating the negative impact of liquidity on stock returns. Thus, the stocks of high liquidity firms had a low return as a result of low-level risks to which firms may be exposed. These findings are consistent with previous studies (Ahmad et al., 2013; Gharaibeh, 2014). However, these findings are also contradicting with other studies (Bergrren \& Bergqvist, 2014; Al-Salamat \& Mustafa, 2016).

The correlation coefficient value between profitability and stock returns is 12.24 and the prob. is 0.0011 , showing the positive impact of profitability on stock returns. Firms with high profitability present a high stock return. Therefore, investors prefer to hold these stocks to obtain a high return. These findings are consistent with previous studies (Yang et al., 2010; Ahmad et al., 2013) but are inconsistent with the results of one study (Bergrren \& Bergqvist, 2014).

The correlation coefficient value between firm size and stock returns is 0.0058 and the prob. is 0.9794 , indicating the negative impact of firm size on stock returns. The possible reason for this result is the higher risks experienced by large firms than that of small firms. The larger the size of a firm, the higher its risks; leading to a decrease in stock returns. This finding is consistent with one study (Bergrren \& Bergqvist, 2014), but it conflicts with other previous studies (Ahmad et al., 2013; Acheampong, 2014).

The results also show that the $\mathrm{R}^{2}$ value is 0.535 , showing the ability of the independent variables represented by growth, financial leverage, liquidity, profitability, and firm size to explain the changes in the dependent variable represented by stock returns by $53.5 \%$.

The value of the Durbin-Watson coefficient is 2.17 , confirming that no multicollinearity problem exists among the study variables (Drury, 2008).

Based on the previous results and given that the prob. for the independent variables reached 0.000 , we have rejected the third null hypothesis and accepted the alternative one that shows a statistically significant impact of financial leverage on stock returns of Jordanian commercial banks listed on the Amman Stock Exchange in the presence of the controlled variables.

$\mathrm{H}_{04}$ : Stock returns has no statistically significant impact on capital structure of Jordanian commercial banks listed on the Amman Stock Exchange in the presence of the controlled variables.

Table 6 represents the results of the multiple linear regression of equation (4), which represents the fourth null hypothesis as follows:

$$
\mathrm{LEV}_{\mathrm{it}}=\mathrm{b}_{0}+\mathrm{b}_{1} \mathrm{GRTH}_{\mathrm{it}}+\mathrm{b}_{2} \mathrm{LIQ}_{\mathrm{it}}+\mathrm{b}_{3} \mathrm{PROF}_{\mathrm{it}}+\mathrm{b}_{4} \mathrm{SR}_{\mathrm{it}}+\mathrm{b}_{5} \mathrm{SZE}_{\mathrm{it}}+\mathrm{e}_{\mathrm{it}}
$$


Table 6. Result of the multiple linear regression based on equation (4)

\begin{tabular}{|l|l|l|l|l|l|l|}
\hline Model & (Constant) & GRTH & LIQ & PROF & SR & SZE \\
\hline Coefficients & -73.6299 & -2.1550 & -4.2632 & -84.0730 & 1.7834 & 15.2717 \\
\hline t-stat. & -5.005 & 1.3908 & 1.9655 & -2.3531 & 1.9240 & 9.7452 \\
\hline Prob. & 0.000 & 0.1243 & 0.0324 & 0.0205 & 0.0571 & 0.000 \\
\hline Notes: implies Significance at level of 5\%; $\mathrm{R}^{2}=0.999 ; \mathrm{Adj} \cdot \mathrm{R}^{2}=0.9989 ;$ F-stat. =4653.9; D.W = 0.92; F-prob. $=0.000$ \\
\hline
\end{tabular}

The results in Table 6 indicate that the correlation coefficient value between growth and financial leverage is 2.1550 , and the prob. is 0.1243 , showing the negative impact of growth on financial leverage. Thus, high-growth firms prefer to rely on their internal sources to fund their operations rather than resorting to debt. These findings are consistent with Yang et al. (2010) but are inconsistent with Ahmad et al. (2013).

The results show that the correlation coefficient value between liquidity and financial leverage is 4.2632 and the prob. is 0.0324 , indicating the negative impact of liquidity on financial leverage. Thus, firms with high liquidity will rely on their internal sources instead of debt to fund their operations. These findings are consistent with previous studies (Ahmad et al., 2013; Gharaibeh, 2014).

The results also show that the correlation coefficient value between profitability and financial leverage is 84.0730 and the prob. is 0.0205 , indicating the negative impact of profitability on financial leverage. Thus, high-profit firms do not prefer debt financing, given that they have sufficient funds to finance their operations. These findings are consistent with previous studies (Yang et al., 2010; Ahmad et al., 2013).

The results show that the correlation coefficient value between stock returns and financial leverage is 1.7834 and the prob. is 0.057 , confirming the positive impact of stock returns on financial leverage, despite the presence of controlled variables. These findings are contradicting with previous studies (Yang et al., 2010; Ahmad et al., 2013; Acheampong, 2014; Gharaibeh, 2014).

The results also indicate that the correlation coefficient value between firm size and financial leverage is 15.2717 and the prob. is 0.000 , indicating the positive impact of firm size on financial leverage. Thus, the more the firm grows bigger, the more money it needs to fund its operations, which will encourage firms to resort to debt. This finding is consistent with Bergrren and Bergqvist (2014) but is inconsistent with Ahmad et al. (2013).

The results also show that the value of $\mathrm{R}^{2}$ is 0.999 , indicating the power of the independent variables represented by growth, liquidity, profitability, stock returns, and firm size to explain the changes in the dependent variable represented by financial leverage by $99.9 \%$.

The value of the Durbin-Watson coefficient is 0.92 , confirming that no multicollinearity problem exists between the study variables (Drury, 2008).

Based on the previous results and given that the prob. for the independent variables reached 0.000 , we have rejected the fourth null hypothesis and accepted the alternative one, which indicates a statistically significant impact of stock returns on financial leverage of Jordanian commercial banks listed on the Amman Stock Exchange, despite the presence of the controlled variables.

\section{Conclusion}

The study has aimed to analyze the relationship between capital structure and stock returns of Jordanian banks listed on the Amman Stock Exchange from 2009 to 2018. A sample of 13 commercial banks is chosen from 16 banks. By the use of an e-views program, descriptive analysis, and correlation analysis, a linear regression analysis is conducted to determine the impact of capital structure as measured by financial leverage as an independent variable on stock returns as a dependent variable. A simple linear regression analysis is also conducted to determine the impact of stock returns as an independent variable on capital structure as a dependent variable. Then, several controlled variables are added, namely, growth in assets, liquidity, firm size, and profitability for each of the two previous equations.

This study has found that growth has a positive impact on stock returns. This finding suggests that the stocks of growing firms are valuable to investors, given that they expect to obtain a high future return from these stocks. Investors' expectations will lead to a higher demand for these stocks, which will also lead to an increase in firms' market value compared with their book value. These findings are consistent with previous studies (Yang et al., 2010; Ahmad et al., 2013; Bergrren \& Bergqvist, 2014). 
This study has found that financial leverage has a positive impact on stock returns, despite the presence of controlled variables. This result is consistent with previous studies (Khan et al., 2013; Bergrren \& Bergqvist, 2014; Ali, 2017) but is inconsistent with other studies (Ahmad et al., 2013; Acheampong, 2014; Gharaibeh, 2014; Al-Salamat \& Mustafa, 2016).

Liquidity has a negative impact on stock returns. Thus, the stocks of high liquidity firms indicate a low return as a result of low risks experienced by such firms. These findings are consistent with previous studies (Ahmad et al., 2013; Gharaibeh, 2014) but are inconsistent with other studies (Bergrren \& Bergqvist, 2014; Al-Salamat \& Mustafa, 2016).

Profitability has a positive impact on stock returns. Firms with high profitability present a high stock return. Therefore, investors prefer to hold these stocks to obtain a high return in the future. These findings are consistent with previous studies (Yang et al., 2010; Ahmad et al., 2013) but are inconsistent with one study (Bergrren \& Bergqvist, 2014).

Firm size has a negative impact on stock returns, given that high risks are more likely to be experienced by large firms than small firms. Thus, the larger the size of a firm, the higher possible risks a firm may experience, which leads to a decrease in stock returns. These findings are consistent with one study (Bergrren \& Bergqvist, 2014) but are inconsistent with other previous studies (Ahmad et al., 2013; Acheampong, 2014).

Growth has a negative impact on financial leverage. High-growth firms prefer to rely on their internal sources to fund their operations rather than resorting to debt. This finding is consistent with Yang et al. (2010) but inconsistent with Ahmad et al. (2013).

Likewise, liquidity has a negative impact on financial leverage. Thus, firms with high liquidity will rely on their internal sources instead of debt to fund their operations. This finding is consistent with previous studies (Ahmad et al., 2013; Gharaibeh, 2014).

Profitability has a negative impact on financial leverage. This finding suggests that high-profit firms do not prefer debt financing, given that they have sufficient funds to finance their operations. This result is consistent with previous studies (Yang et al., 2010; Ahmad et al., 2013).

By contrast, stock returns have a positive impact on financial leverage, despite the presence of controlled variables. This finding is inconsistent with previous studies (Yang et al., 2010; Ahmad et al., 2013; Acheampong, 2014; Gharaibeh, 2014).

Likewise, firm size has a positive impact on financial leverage. Thus, the more the firm grows bigger, the more money it needs to fund its operations. Firms will be encouraged to resort to debt. These findings are consistent with Bergrren and Bergqvist (2014) but are inconsistent with Ahmad et al. (2013).

Based on the results of this study, we offer the following recommendation:

1. Jordanian commercial banks must decrease the financial leverage in their capital structure to achieve a higher return on their stocks.

2. Banks must manage their profits efficiently to increase their stock returns.

3. Future research needs to add more control variables such as market returns, interest rates, taxes, and macroeconomic variables including inflation, GDP growth, and monetary policy.

The limitations of this study are as follows. This study is limited to Jordanian commercial banks listed on the Amman Stock Exchange. Thus, generalizing the results to other commercial banks in other countries is unlikely. This study is also limited to the period of 2009-2018. Results could not be adopted for other periods, given that they could change as the period changes. Finally, the study is limited to several control variables, namely, firm size, profitability, growth, and liquidity. Results can change if other control variables are added or one of the control variables is omitted."

\section{References}

Abor, J. (2005). The effect of capital structure on profitability: An empirical analysis of listed firms in Ghana. Journal of Risk Finance, 6(5), 438-445. https://doi.org/10.1108/15265940510633505

Acheampong, P., Agalega, E., \& Shibu, A. K. (2014). The Effect of Financial Leverage and Market Size on Stock Returns on the Ghana Stock Exchange: Evidence from Selected Stocks in the Manufacturing Sector. International Journal of Financial Research, 5(1), 125-134. https://doi.org/10.5430/ijfr.v5n1p125

Aharon, D. Y., \& Yagil, Y. (2019). The Impact of Financial Leverage on the Variance of Stock Returns. International Journal of Financial Studies, 7(1), 1-18. https://doi.org/10.3390/ijfs7010014 
Ahmad, H., Fida, B. A., \& Zakaria, M. (2013). The Co-determinants of Capital Structure and Stock Returns: Evidence from the Karachi Stock Exchange. The Lahore Journal of Economics, 18(1), 81-92. https://doi.org/10.35536/lje.2013.v18.i1.a4

Ali, S. (2017). Impact of Capital Structure on Stock Return in Oil \& Gas Sector of Pakistan. Journal of Energy Technologies and Policy, 7(4), 12-20. Retrieved from https://www.iiste.org/Journals/index.php/JETP/article/view/36613

Aliyu, S. U. R. (2011). Does inflation has an impact on Stock Returns and Volatility? Evidence from Nigeria and Ghana. Applied Financial Economics, 22(6), 427-435. https://doi.org/10.1080/09603107.2011.617691

Al-Salamat, W., \& Mustafa, H. (2016). The Impact of Capital Structure on Stock Return: Empirical Evidence from Amman Stock Exchange. International Journal of Business and Social Science, 7(9), 183-196. Retrieved from http://ijbssnet.com/journals/Vol_7_No_9_September_2016/19.pdf

Al-Yahyaee, K., Pham, T., \& Walter, T. (2013). Capital structure and stock returns: Evidence from an emerging market with unique financing arrangements. Applied Financial Economics, 23(14), 1197-1203. https://doi.org/10.1080/09603107.2013.799754

Antoniou, A., Guney, Y., \& Paudyal, K. (2008). The determinants of capital structure: Capital market-oriented versus bank-oriented institutions. Journal of Financial and Quantitative Analysis, 43(1), 59-92. https://doi.org/10.1017/S0022109000002751

Baker, M., \& Wurgler, J. (2002). Market timing and capital structure. The Journal of Finance, 57(1), 1-32. https://doi.org/10.1111/1540-6261.00414

Berggren, S., \& Bergqvist, A. (2014). Capital Structure and Stock Returns-A study of the Swedish large cap companies. Unpublished Bachelor Thesis, University of Gothenburg.

Bhandari, L. C. (1988). Debt/equity ratio and expected common stock returns: Empirical evidence. Journal of finance, 43(2), 507-528. https://doi.org/10.1111/j.1540-6261.1988.tb03952.x

Bodie, Z., Kane, A., \& Marcus, A. (2008). Investments (7th ed.). McGraw-Hill, New York.

Brav, O. (2009). Access to capital, capital structure, and the funding of the firm. The Journal of Finance, 64(1), 263-308. https://doi.org/10.1111/j.1540-6261.2008.01434.x

Brealey, R., Myers, S., \& Allen, F. (2011). Principles of Corporate Finance (10th ed.). McGraw-Hill/Irwin, New York.

Chen, S. Y., \& Chen, L. J. (2011). Capital structure determinants: An empirical study in Taiwan. African Journal of Business Management, 5(27), 10972-10983. https://doi.org/10.5897/AJBM10.1334

Chowdhury, A., \& Chowdhury, S. P. (2010). Impact of capital structure on firm's value: Evidence from Bangladesh. Business and Economic Horizons, 3(3), 111-122. https://doi.org/10.15208/beh.2010.32

Daferighe, E., \& Sunday, C. S. (2012). The impact of inflation on stock market performance in Nigeria. American Journal of Social and Management Sciences, 3(2), 76-82. http://doi:10.5251/ajsms.2012.3.2.76.82

Drury, C. (2008). Cost \& Management Accounting (7th ed.). Cengage Learning, London.

Dudley, E., \& James, C. M. (2015). Cash flow volatility and capital structure choice. https://dx.doi.org/10.2139/ssrn.2492152

Frimpong, M. J. (2010). Corporate Financial Strategy. Kumasi, KNUST Printing Press.

Gallizo, J., \& Salvador, M. (2006). Share prices and accounting variables: a hierarchical Bayesian analysis. Review of Accounting and Finance, 5(3), 268-278. https://doi.org/10.1108/14757700610686813

Gharaibeh, A. (2014). Capital structure, Liquidity, and Stock returns. European Scientific Journal, 10(25), 171-179. Retrieved from https://eujournal.org/index.php/esj/article/view/4271/4093

Hass, M. (2002). Earning management in two-period principle, Agents-Model, GEABA Discussion Paper No. 00-02. https://dx.doi.org/10.2139/ssrn.308563

Ilyas, J. (2008). The determinants of capital structure: Analysis of non-financial firms listed in Karachi stock exchange in Pakistan. Journal of Managerial Sciences, 2(2), 279-307. Retrieved from http://www.qurtuba.edu.pk/jms/2_2.html

Jahanzeb, A. (2013). Trade-off theory, pecking order theory and market timing theory: a comprehensive review 
of capital structure theories. Economics Bulletin, 33(1), 1-6.

Khan, W., Naz, A., Khan, M., Khan, Q., \& Ahmad, S. (2013). The Impact of Capital Structure and Financial Performance on Stock Returns, a case of Pakistan Textile Industry. Middle-East Journal of Scientific Research, 16(2), 289-295.

Modigliani, F., \& Miller, M. (1958). The cost of capital, corporation finance and the theory of investment". American Economic Review, 48(3), 261-297. Retrieved from https://www.jstor.org/stable/1809766

Mugambi, M., \& Okech, T. (2016). Effect of Macroeconomic variables on Stock Returns of listed commercial Banks in Kenya. International Journal of Economics, Commerce and Management, 4(6), 390-418. Retrieved from http://ijecm.co.uk/wp-content/uploads/2016/06/4622.pdf

Muzir, E. (2011). Triangle relationship among firm size, capital structure choice and financial performance. Journal of Management Research, 11(2), 87-98. Retrieved from http://52.172.159.94/index.php/jmr/article/view/37294

Myers, S. C. (1984). The capital structure puzzle. The journal of finance, 39(3), 574-592. https://doi.org/10.1111/j.1540-6261.1984.tb03646.x

Myers, S. C., \& Majluf, N. S. (1984). Corporate financing and investment decisions when companies have information that investors do not have. Journal of financial economics, 13(2), 187-221. https://doi.org/10.1016/0304-405X(84)90023-0

Onaolapo, A. A., \& Kajola, S. O. (2010). Capital structure and firm performance: Evidence from Nigeria. European Journal of Economics, Finance and Administrative Science, 25, 70-82.

Örtqvist, D., Masli, E. K., Rahman, S. F., \& Selvarajah, C. (2006). Determinants of Capital Structure in New Ventures: Evidence from Swedish Longitudinal Data. Journal of Developmental Entrepreneurship, 11(4), 277-296. https://doi.org/10.1142/S1084946706000477

Pervan, M., \& Višić, J. (2012). Influence of Firm Size on Its Business Success. Croatian Operational Research Review (CRORR), 3(1), 213-223. Retrieved from https://hrcak.srce.hr/96821

Taofik, M. I., \& Omosola, M. A. (2013). The Relationship between Stock Return and Inflation in Nigeria. European Scientific Journal, 9(4), 146-157. Retrieved from https://eujournal.org/index.php/esj/article/view/772

Umar, M., Tanveer, Z., Aslam, S., \& Sajid, M. (2012). Impact of capital structure on firms' financial performance: Evidence from Pakistan. Research Journal of Finance and Accounting, 3(9), 1-12. Retrieved from https://www.iiste.org/Journals/index.php/RJFA/article/view/3145

Welch, I. (2004). Capital Structure and Stock Returns. Journal of Political Economy, 112(1), 106-132. https://doi.org/10.1086/379933

Yang, C. C., Lee, C. F., Gu, Y. X., \& Lee, Y. W. (2010). Co-determination of capital structure and stock Returns-A LISREL approach: An empirical test of Taiwan stock markets. Quarterly Review of Economics and Finance, 50(2), 222-233. https://doi.org/10.1016/j.qref.2009.12.001

\section{Copyrights}

Copyright for this article is retained by the author(s), with first publication rights granted to the journal.

This is an open-access article distributed under the terms and conditions of the Creative Commons Attribution license (http://creativecommons.org/licenses/by/4.0/). 